\title{
Dehumdifier Heat Pump Dryer for Corn Drying and Process Characterization
}

\author{
Anis Arendra \\ Mechanical Engineering Department \\ University of Trunojoyo Madura \\ Bangkalan, Indonesia \\ anis.arendra@trunojoyo.ac.id
}

\author{
Sabarudin Akhmad, Ida Lumintu \\ Industrial Engineering Department \\ University of Trunojoyo Madura \\ Bangkalan, Indonesia \\ sabarutm@gmail.com
}

\begin{abstract}
How to build a corn dryer that is not weather dependent yet energy efficient? And how the characteristics of corn dryer?. This research objectives are: Design and develop a dehumidifier heat pump dryer for corn drying. Observing the characteristics of drying time, temperature and humidity of drying air and consumption of drying energy. This study consists of two stages. First, design and build a dehumidifier heat-pump dryer for corn and instrumentation to monitor the drying process parameters. Second, characterizing the process of drying the corn using a dehumidifier heat-pump dryer to build a knowledge base for the corn drying. The results of the study were concluded. The lower the speed setting of blower fan, the higher the air temperature of the dehumidifier heat pump dryer. The highest drying air temperature in this study was only 53C. The lower the evaporator temperature setting, the lower the drying air humidity. The lowest drying air humidity in this study reached $19 \%$.
\end{abstract}

Keywords-corn; dehumidifier heat pump dryer; relative humidity

\section{INTRODUCTION}

Corn as one of the important carbohydrate-producing food crops besides rice and wheat. As a producer of carbohydrates, corn is used for staple foods, animal feed industry, cornstarch, cooking oil, ethanol [1]. Because of that, the demand for corn continues to increase from year to year. Increased demand for corn is seen in the export-import statistics of agricultural commodities 2001-2013 issued by the Directorate General of Processing and Marketing of Agricultural Products, the Ministry of Agriculture, Republic of Indonesia[2]. Chafid [1] describes the research on corn production and forecasting for the next 5 years period of data on corn import production and exports in the outlook for agricultural commodities in the corn food sub-sector. It is projected that there will be an increase in corn production in the 2016-2019 period and a surplus in 2016. The corn production surplus is expected to decrease in 2014 due to the increasing demand for corn for the animal feed industry.

Efforts to maintain the availability of corn commodity stocks must be accompanied by efforts to maintain the quality of corn stocks. The quality of corn will be well maintained if stored in conditions of moisture content below $14 \%$ wet base according to SNI 01-3920-1995 standard [3]. The popular traditional way to dry corn is to dry it directly in the sunshine. This method is mostly done in tropical countries $[4,5,6]$. This method is mostly done because of low cost considerations [7, 8]. But this method of drying in the sunshine also has many shortcomings, including poor quality results due to uneven drying rates [4], drying process and quality results that are very weather dependent [6], and food safety issues due to pollutants [5]. The various corn drying methods that have been done to overcome the shortcomings of sunshine drying are: using zeolite [3], microwave wave radiation [9], infrared radiation [10], and heat pump technology [11].

The drying process consumes large amounts of energy in many industries, including the food processing industry. Drying energy is needed in the process of phase change and transport of water to the vapor phase [12]. In drying using sunshine this energy is obtained for free and abundant to evaporate water [7]. But the drying process in the industry requires other energy sources from microwave radiation [9], infrared radiation [10] and heat pump technology [11]. This energy cost is not inexpensive, so technology is needed to optimize the use of drying energy. Among the technologies used are intermittent drying [13], absorbent material to absorb moisture[3]. Besides that, heat pump technology can save energy consumption by taking away wasted heat energy from the environment. Sosie [11] takes the latent heat of condensation to increase the air temperature of the dryer using a heat pump. To achieve optimal results and low costs, the drying process parameters must be monitored and controlled appropriately[12, 14].

\section{OBJECTIVE AND RESEARCH METHOD}

From the research background description, it can be summarized that there are important issues that must be resolved for good quality dry corn production. How to build a corn dryer that is not weather dependent yet energy efficient? How the characteristics of drying corn using a developed dryer? Based on the formulation of the problem raised in this study, the research objectives are: Design and develop a dehumidifier heat pump dryer for corn drying. Observing the characteristics of drying time, corn moisture content, temperature and humidity of drying air and consumption of drying energy. This study consists of two stages. First, design and build a dehumidifier heat-pump dryer for corn and 
instrumentation to monitor the drying process parameters. Second, characterizing the process of drying the corn using a dehumidifier heat-pump dryer to build a knowledge base for the corn drying. The first phase of this research is to build a drying machine and instrumentation for dehumidifier heat pump dryer. Study of drying system design, designing system and drying machine components, and instrumentation components, procurement of drying machine components and instrumentation components, manufacturing the drying machines, developing process parameter instrumentation, and testing the drying machines. The second phase of this research is the characteristic test of corn drying process using a dehumidifier heat pump dryer. Starting from experimental design, research hypotheses, research setup preparation, research data collection, data processing and analysis of research results.

\section{EXPERIMENT SETUP AND MEASUREMENT}

The independent variables for the characteristic test of corn drying process using a dehumidifier heat pump dryer are:

\section{$\mathrm{X} 1$. Speed blower fan}

\section{$\mathrm{X} 2$. Evaporator temperature}

\section{X3. Drying time}

\section{$\mathrm{X} 4$. Initial weight}

The dependent variable for the characteristic test of corn drying process using a dehumidifier heat pump dryer are:

\section{Y1. Dryer air temperature}

Y2. Relative humidity of drying chamber air

Each factor of independent variables is divided into three level factors:

\section{X1. Speed blower fan: Low, medium, High}

$\mathrm{X} 2$. Evaporator temperature: $17^{0} \mathrm{C}, 20^{\circ} \mathrm{C}, 23^{\circ} \mathrm{C}$.

X3. Drying time: 150 minute

X4. Initial weight: $10 \mathrm{~kg}$. study.

Following is an experimental procedure conducted in this

1. Preparation of the dryer machine

2. Installation of electrical power by plugging into a power outlet and energy meter correctly.

3. Press the $\mathrm{ON}$ button available on the remote.

4. Setting the temperature of evaprator and blower speed fan according to the specified machine:

a. Direct the remote to Air Conditioner Unit

b. Press the mode and press the button upwards to increase the evaporator's temperature level. c. Press mode and press the button downwards to reduce the evaporator's temperature level.

d. Press mode and press the button to the right to increase the level of the blower speed fan.

e. Press mode and press the button to the left to lower the blower speed fan level.

5. Prepare the period of time of corn to be dried

6. Prepare instrumentation to monitor air temperature and humidity, do datalog acquisition.

7. Run the dryer and set the timer.

8. After the time limit is reached, turn off the dryer and unload dryed corn.

9. Record the drying energy consumed

10. Weigh and record the time period to drying.

11. Save the dryer air datalog.

\section{RESUlt AND DisCUSSION}

The results of measurements of temperature and relative humidity of the drying air in dehumidifier heat pump dryer are shown in figure 1 through figure 9. The ' $A$ ' data series is the data of drying air before entering the drying chamber, and the ' $\mathrm{B}$ ' data series is the data of the air leaving the drying chamber. The dehumidifier heat pump dryer is run for 150 minutes to drying $10 \mathrm{~kg}$ of wet corn. Air temperature and drying air humidity reach steady state after 20-30 minutes after the dryer is turned on (Table I). The fastest setling time, 20 minutes on the evaporator temperature parameter $17^{\circ} \mathrm{C}$ (figure 1) or the high speed fan setting parameter (figure 7). This is due to at the lowest temperature setting $17^{\circ} \mathrm{C}$, the dehumidifier heat pump dryer works at full power so that the dryer reaches steady state conditions faster. Likewise on high speed fan settings, air circulation runs faster so that it reaches steady state conditions faster. The longest setling time at the medium speed fan setting parameter with evaporator temperature $23^{\circ} \mathrm{C}$ (figure 6), reaches 35 minutes. This happens because the dehumidifier heat pump dryer works on the lowest power setting so it cannot immediately reach the stedy state condition.

The drying air temperature leaving out of the drying chamber is always lower than the drying air temperature that enters the drying chamber (Table II). This is due to the process of evaporation of corn water content taking heat energy from the drying air. The highest average dryer air temperature is $52^{\circ} \mathrm{C}$ reached at the low speed fan setting (figure $1,2,3$ ), and vice versa the average lowest drying air temperature $50{ }^{\circ} \mathrm{C}$ is reached at the high speed fan setting (figure 7, 8,9). This is due to at low speed fan air circulating slower than at high speed fan settings, so that the heat transfer between the heat exchanger and the air goes better. The heat released by the heat exchanger is received by less air circulation on the low speed fan setting so that the temperature increases higher.

Table III also shows that there is an increase in drying air humidity after leaving the drying chamber. This shows that the drying air comes out carrying moisture which comes from the water content of the corn. The lowest average humidity is 
reached at the lowest evaporator temperature setting of $17^{\circ} \mathrm{C}$ (figures 1, 4, 7), at $20 \%$ relative humidity. The highest air humidity is reached at highest evaporator temperature setting $23^{\circ} \mathrm{C}$ (figure $\left.3,6,9\right)$ of $22 \%$ relative humidity. This happens because at the lowest evaporator temperature setting, the contact surface of the evaporator reaches below the dew point is able to produce the most condensate compared to the higher temperature setting, $20^{\circ} \mathrm{C}$ or $23^{\circ} \mathrm{C}$. So that with more and more moisture vapor condensate is formed, the dryer air humidity decreases.
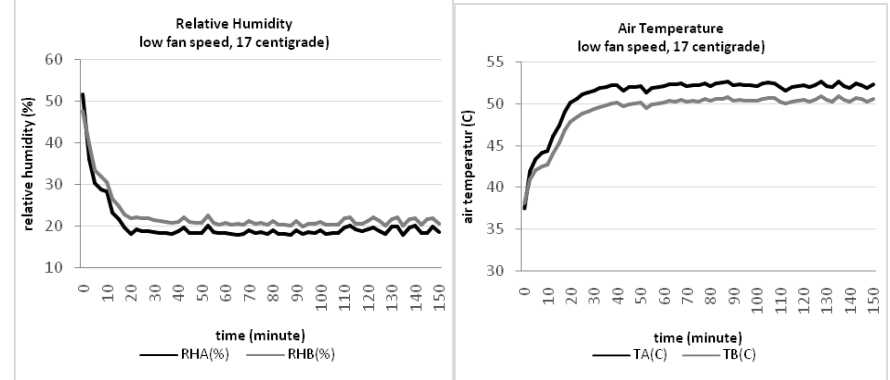

Fig. 1. Dryer air temperature and relative humidity, low fan speed, $17^{\circ} \mathrm{C}$.
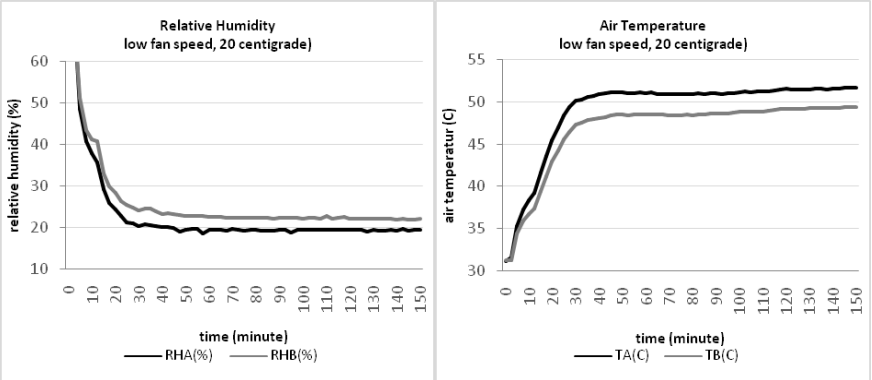

Fig. 2. Dryer air temperature and relative humidity, low fan speed, $20^{\circ} \mathrm{C}$.
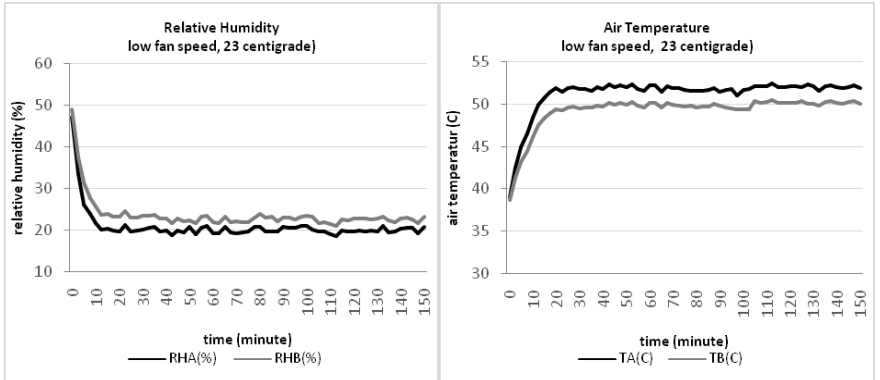

Fig. 3. Dryer air temperature and relative humidity, low fan speed, $23^{\circ} \mathrm{C}$.
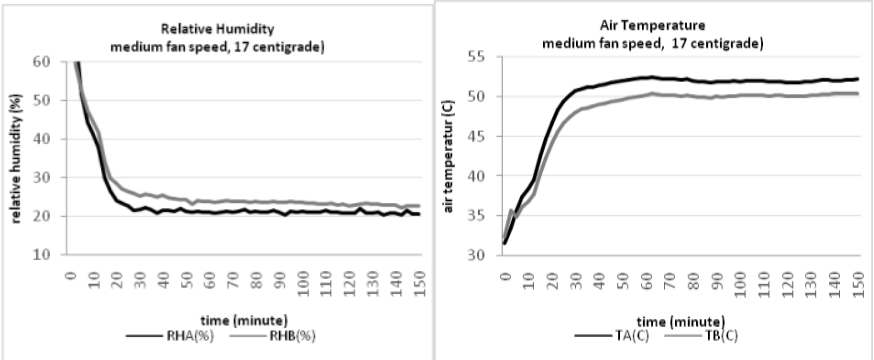

Fig. 4. Dryer air temperature and relative humidity, medium fan speed, $17^{\circ} \mathrm{C}$.

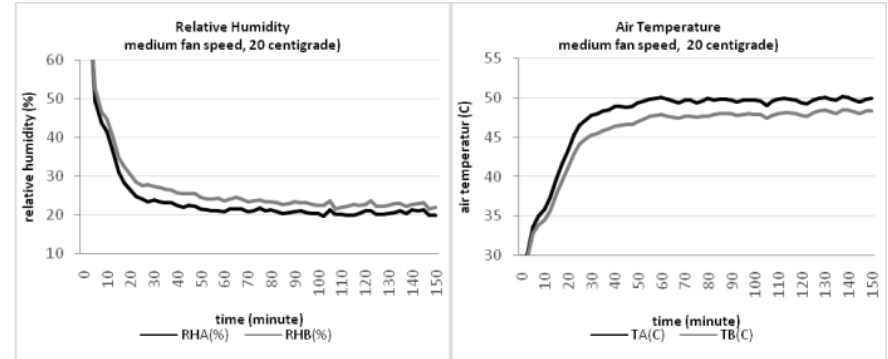

Fig. 5. Dryer air temperature and relative humidity, medium fan speed, $20^{\circ} \mathrm{C}$.

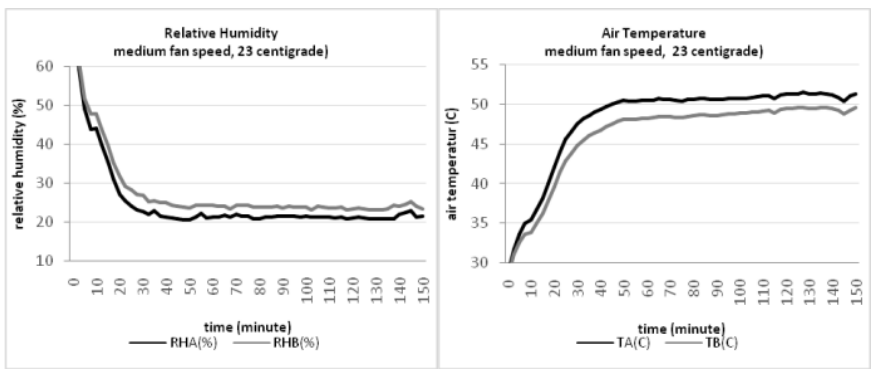

Fig. 6. Dryer air temperature and relative humidity, medium fan speed, $23^{\circ} \mathrm{C}$.

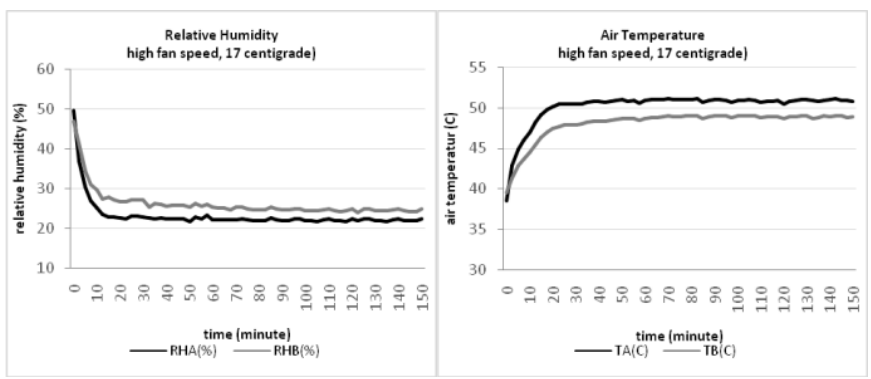

Fig. 7. Dryer air temperature and relative humidity, high fan speed, $17^{\circ} \mathrm{C}$.

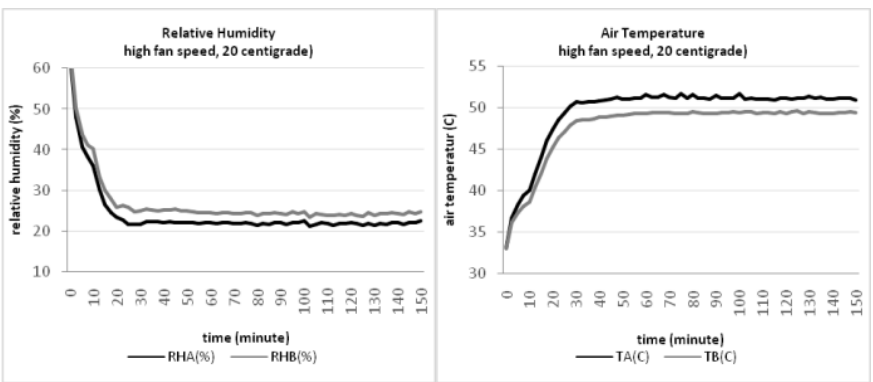

Fig. 8. Dryer air temperature and relative humidity, high fan speed, $20^{\circ} \mathrm{C}$.

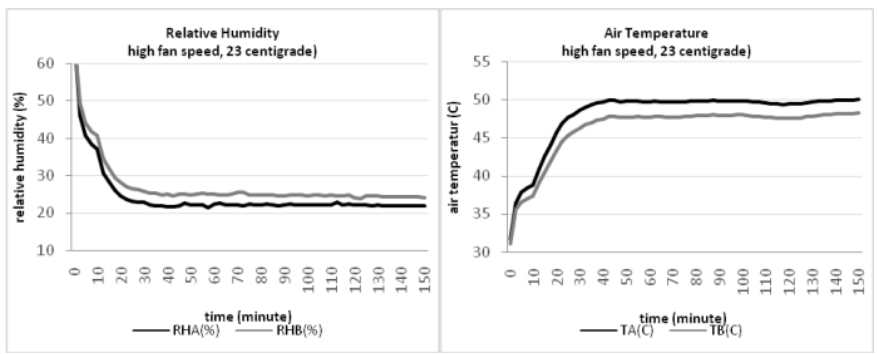

Fig. 9. Dryer air temperature and relative humidity, high fan speed, $23^{\circ} \mathrm{C}$. 
TABLE I. S SetLing Time To Steady State

\begin{tabular}{|c|c|c|c|c|}
\hline \multirow{2}{*}{\multicolumn{2}{|c|}{$\begin{array}{l}\text { setling time } \\
\text { (minute) }\end{array}$}} & \multicolumn{3}{|c|}{ Fan Speed } \\
\hline & & low & med & high \\
\hline \multirow{3}{*}{ 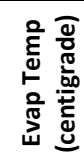 } & 17 & 20 & 25 & 20 \\
\hline & 20 & 25 & 30 & 25 \\
\hline & 23 & 30 & 35 & 30 \\
\hline
\end{tabular}

TABLE II. MAXIMUM INLET - OUTLET AIR TEMPERATUR

\begin{tabular}{|c|c|c|c|}
\hline \multirow{2}{*}{$\begin{array}{c}\max \\
\text { inlet air } \\
\text { temp }\left({ }^{\circ} \mathrm{C}\right)\end{array}$} & \multicolumn{3}{|c|}{ Fan Speed } \\
\hline & low & med & high \\
\hline 을 웡 17 & 53 & 52 & 51 \\
\hline 20 & 52 & 51 & 51 \\
\hline 23 & 52 & 51 & 51 \\
\hline
\end{tabular}

\begin{tabular}{|c|c|c|c|c|}
\hline \multirow{2}{*}{\multicolumn{2}{|c|}{$\begin{array}{c}\text { max } \\
\text { outlet } \\
\text { air } \\
\text { temp }\left({ }^{\circ} \mathrm{C}\right)\end{array}$}} & \multicolumn{3}{|c|}{ Fan Speed } \\
\hline & & low & med & high \\
\hline \multirow{3}{*}{ 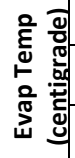 } & 17 & 51 & 50 & 49 \\
\hline & 20 & 50 & 49 & 49 \\
\hline & 23 & 50 & 49 & 49 \\
\hline
\end{tabular}

TABLE III. MINIMUM INLET - OUTLET AIR HUMIDITY

\begin{tabular}{|c|c|c|c|}
\hline \multirow{2}{*}{$\begin{array}{c}\text { max } \\
\text { inlet air } \\
\text { humidity }\end{array}$} & \multicolumn{3}{|c|}{ Fan Speed } \\
\hline & low & med & high \\
\hline 으 & $19 \%$ & $20 \%$ & $21 \%$ \\
\hline 20 & $20 \%$ & $20 \%$ & $21 \%$ \\
\hline Ш 드 & $20 \%$ & $21 \%$ & $21 \%$ \\
\hline
\end{tabular}

\begin{tabular}{|c|c|c|c|}
\hline \multirow{2}{*}{$\begin{array}{c}\text { max } \\
\text { outlet } \\
\text { air } \\
\text { humidity }\end{array}$} & \multicolumn{3}{|c|}{ Fan Speed } \\
\hline & low & med & high \\
\hline 을 จ 17 & $21 \%$ & $21 \%$ & $23 \%$ \\
\hline 20 & $22 \%$ & $21 \%$ & $23 \%$ \\
\hline 23 & $22 \%$ & $23 \%$ & $23 \%$ \\
\hline
\end{tabular}

\section{CONCLUSION}

Based on the observations of the study concluded that. The lower the speed setting of the fan blower, the higher the air temperature of the dryer. The highest drying air temperature in this study was only 53C. The lower the evaporator temperature setting, the lower the drying air humidity. The lowest drying air humidity in this study reached $19 \%$.

\section{REFERENCES}

[1] M. Chafid, Outlook Komoditas Pertanian Subsektor Pangan Jagung, 2015, downloaded from https://pse.litbang.pertanian.go.id/ind.

[2] Direktorat Jenderal Pengolahan dan Pemasaran Hasil Pertanian Kementrian Pertanian RI, Statistik Ekspor Impor Komoditas Pertanian 2001-2013, vol. 1. 2014, downloaded from http://www.agribisnis.net

[3] M. Djaeni, N. Aishah, H. Nissaulfasha, and L. Buchori, "Corn Drying with Zeolite in The Fluidized Bed Dryer under Medium Temperature," J. Technol. Sci., vol. 24, pp. 13-18, 2013.

[4] J. Iqbal and M. Ahmad, "Comparative performance of selected ear corn drying techniques,” J. Eng. Appl. Sci., vol. 9, pp. 574-579, 2014.

[5] A. Lundberg and L. Magnusson, "Profitability and competitiveness of grain handling at farm level," unpublished.

[6] A.D. Chauhan, N. Seth, D.K. Vyas, and N. Kumar, "a Review of Different Drying Techniques of Freshly Harvested Maize Cobs," Int. J. Agric. Sci. Res., vol. 7, pp. 173-180, 2017.

[7] A.A. Gatea, "Design, construction and performance evaluation of solar maize dryer," J. Agric. Biotechnol. Sustain. Dev., vol. 2, pp. 39-46, 2010.

[8] T.K. Stephen, "Design and Evaluation of Solar Maize Grain Dryer with a Back-up Heater," unpublished.

[9] S. Gursoy, R. Choudhary, D.G. Watson, and S. Gürsoy, "Microwave drying kinetics and quality characteristics of corn," Int. J. Agric. Biol. Eng., vol. 6, pp. 90-99, 2013.

[10] S. Wilson, "Development of Infrared Heating Technology for Corn Drying and Decontamination to Maintain Quality and Prevent Mycotoxins," unpublised.

[11] V. Sosie, "A Heat Pump Dehumidifier assisted Dryer for Agri-foods," unpublished.

[12] P. Dufour, "Control Engineering in Drying Technology: Review and Trends," Spec. issue Dry. Technol. Prog. Dry. Technol., vol. 7, pp. 889904, 2006.

[13] R.O. Defendi, P.R. Paraíso, L. Mario, and D.M. Jorge, "Assessment of dryer performance under intermittent drying of grains in fixed bed," Engevista, vol. 19, pp. 146-165, 2017.

[14] A. Arendra, S. Akhmad, M. Mualim, and K. Hidayat, "Development and Process Characterization of Low Cost Heat Pump Dehumidifier for Crackers Dryer," 2018 [Int. Conf. Life Innov. Change Knowl., 2018]. 